\title{
The Predictors of Graduation: Social Skills, Mental Health, Academic Characteristics ${ }^{1}$
}

\author{
Alessandra Salina Brandão \\ Instituto de Análise do Comportamento \\ de Bauru, Bauru-SP, Brazil
}

\author{
Alessandra Turini Bolsoni-Silva \\ Universidade Estadual Paulista Júlio de \\ Mesquita Filho, Bauru-SP, Brazil
}

\author{
Sonia Regina Loureiro \\ Universidade de São Paulo, Ribeirão \\ Preto-SP, Brazil
}

\begin{abstract}
Not completing the undergraduate course in the time expected in the curricula can put the universities and students at a disadvantage, with a delay to enter the labor market. The aim was to identify predictors of graduation, considering social skills, mental health, initial academic performance and socio-demographic and academic characteristics. In total, 287 students participated, of both genders and from the humanities, exact and biological areas, who answered the instruments: Social Skills, Behaviors and Context Assessment Questionnaire for University Students, Short version of the Social Phobia Inventory, Beck Depression Inventory, and Structured Clinical Interview for DSM-IV. Predictors were: female, humanities area and average or above-average initial academic performance. The social skills and mental health differentiated the groups in the univariate analyses. This data suggests a need for attention to academic performance in the initial stages of the course, and preventive measures for male students of the exact and biological areas.
\end{abstract}

Keywords: academic achievement, college students, mental health, social skills

\section{Preditores da Conclusão da Graduação: Habilidades Sociais, Saúde Mental, Características Acadêmicas}

\begin{abstract}
Resumo: Não concluir a graduação no tempo previsto pode trazer ônus para as universidades e estudantes, com atraso na inserção no mercado profissional. Objetiva-se identificar variáveis preditoras da conclusão da graduação, considerando habilidades sociais, saúde mental, desempenho acadêmico inicial e características sociodemográficas e acadêmicas. Participaram 287 universitários, de ambos os sexos, das áreas de humanas, exatas e biológicas, os quais responderam aos instrumentos: Questionário de Avaliação de Habilidades Sociais, Comportamentos e Contextos para Universitários, Versão reduzida do Inventário de Fobia Social, Inventário de Depressão de Beck e Entrevista Clínica Estruturada - DSM-IV. Foram preditores da conclusão da graduação: sexo feminino, área de humanas e desempenho acadêmico inicial na média ou acima da média. As habilidades sociais e saúde mental diferenciaram os grupos nas análises univariadas. Tais dados sugerem a necessidade de atenção ao desempenho acadêmico nas fases iniciais dos cursos e medidas preventivas para os universitários homens, das áreas de exatas e biológicas.
\end{abstract}

Palavras-chave: rendimento escolar, estudantes universitários, saúde mental, habilidades sociais

\section{Predictores de la Conclusión del Curso: Habilidades Sociales, Salud Mental, Características Académicas}

\begin{abstract}
Resumen: No concluir el curso de pregrado dentro del tiempo previsto puede causar perjuicios para las universidades y los estudiantes, retrasando la incorporación al mercado de trabajo. La finalidad es identificar variables predictivas de la conclusión del pregrado, considerando habilidades sociales, salud mental, desempeño académico inicial y características sociodemográficas y académicas. Participaron 287 universitarios, de ambos sexos y en las áreas de ciencias exactas, biológicas y humanas, que contestaron los instrumentos: Cuestionario de Evaluación de Habilidades Sociales, Comportamientos y Contextos para Universitarios, Versión reducida del Inventario de Fobia Social, Inventario de Depresión de Beck y Entrevista Clínica Estructurada para el DSM-IV. Fueron predictivos de la conclusión del curso de pregrado dentro del tiempo previsto: sexo femenino, área de humanas y desempeño académico inicial dentro del promedio o superior al promedio, siendo que habilidades sociales y salud mental distinguieron los grupos en los análisis univariados. Tales datos sugieren la necesidad de atención al desempeño académico en las fases iniciales del curso, y medidas preventivas para los universitarios masculinos de las áreas de exactas y biológicas.
\end{abstract}

Palabras clave: rendimiento escolar, estudiantes universitarios, salud mental, habilidades sociales

\footnotetext{
${ }^{1}$ Paper deriving from the doctoral dissertation by the author under the supervision of Dr. Sonia Regina Loureiro, defended in 2016, in the Graduate Program in Psychology at Faculdade de Filosofia Ciências e Letras de Ribeirão Preto-USP. Support: The study received funding from CAPES
}

\author{
${ }^{2}$ Correspondence address: \\ Alessandra Salina Brandão. Rua Anvar Dabus, n. 2-80. Jardim Mariana, \\ CEP: 17017-120. Bauru-SP, Brasil. E-mail: alessandrasalina@gmail.com
}


The graduation period is an important moment in the development of young people, when they prepare for and are inserted in the job market. Graduation difficulties can entail losses for the students and the university, with personal disadvantages and use of the university's human and financial resources (Martí Ballester, 2012). Data from the Brazilian Department of Education and Culture (MEC) for 2010 indicated drop-out rates of $13.2 \%$ and $15.6 \%$ from Brazilian public and private universities, respectively (Borges, 2012), representing a considerable number of college students with difficulties.

The students' academic performance can be related with different variables, such as the students' study (Costales \& Neira, 2011) and pedagogical organization skills (Martí Ballester, 2012). In this scenario, other variables have been considered relevant to understand the academic performance, such as social skills (Aguilar, 2008; Artino et al., 2012; Fernandez, Salamonson, \& Griffiths, 2012; Gomes \& Soares, 2013; Ihm, Lee, Kim, Jang, \& Jin, 2013; Oyarzún Iturra, Estrada Goic, Pino Astete, \& Oyarzún Jara, 2012; Victoroff $\&$ Boyatzis, 2013); mental health conditions, such as anxiety (Costales \& Neira, 2011; Hernández-Pozo, Coronado Álvarez, Araújo Contreras, \& Cerezo Reséndiz, 2008), depression (Gonçalves, Zidan, Issa, \& Barah, 2012; Turner, Thompson, Huber, \& Arif, 2012) and drugs use (Bajwa et al., 2013; Castaño-Perez \& Calderon-Vallejo, 2014); besides academic variables like knowledge areas (Garzella, 2013) and courses (Martí Ballester, 2012).

As regards the social skills, it is verified that there is no consensus regarding their influence on college students' academic performance. Some studies indicate a positive relation between a good social skills repertoire and satisfactory academic performance (Aguilar, 2008; Artino et al., 2012; Fernandez et al., 2012; Oyarzún Iturra et al., 2012; Victoroff \& Boyatzis, 2013). In the study by Nuñez Del Arco (2005), no significant correlation as identified between these variables and Gomes and Soares (2013) identified that the relation between social skills and academic performance varied according to specific social skills factors. Students with higher mean scores in the factor Coping and Self-assertion with risk obtained higher mean academic performance scores, while students with higher mean scores in the factor Conversation obtained lower mean academic performance scores. Ihm et al. (2013) identified that the interpersonal communication skills were negatively related with the academic performance.

As verified, most studies on this theme had correlational designs (Artino et al., 2012; Fernandez et al., 2012; Nuñez Del Arco, 2005; Oyarzún Iturra, 2012; Victoroff \& Boyatzis, 2013), while only the studies by Gomes and Soares (2013) and $\mathrm{Ihm}$ et al. (2013) used predictive methods. Ihm et al. (2013) adopted social skills and academic performance measures at different moments in the course and Gomes and Soares (2013) assessed only the start of the course, indicating the need for further research on the temporal scope of the relations between the social skills repertoire and academic performance.

As for the relation between mental health and academic performance, among the studies identified, it was verified that mental health problems like anxiety, depression and drugs use negatively affect the college students' academic performance (Bajwa et al., 2013; Castaño-Perez \& Calderon-Vallejo, 2014; Costales \& Neira, 2011; Hernández-Pozo et al., 2008; Turner et al., 2012), except in Costa et al. (2012), who found a relation between depression indicators and good academic performance. In the analysis of these studies, it is verified that the majority found a relation between mental health indicators and academic difficulties. As a gap, the predominant use of screening tools instead of diagnostic instruments is highlighted.

With regard to the sociodemographic variables, Martí Ballester (2012) analyzed the approval of college students in a specific Financial Accounting subject and found higher approval frequencies for women than for men, proposing that future studies include global academic performance measures, such as graduation.

Another important set of variables that can interfere in the academic performance of college students relates to the academic characteristics, such as course, year of graduation and knowledge area. Martí Ballester (2012) investigated the course variable, comparing the academic performance of undergraduate students in Economics and Business Administration. The author found a better academic performance for first-year students, suggesting the need for future studies to compare a larger number of courses. Garzella (2013) contributed to the analysis of academic variables, specifically the description of college students' academic performance in the exact sciences. When discussing the pedagogical practices of professors in the subject Calculus I, the author found a dropout rate of up to $77.5 \%$, which highlights the students' academic difficulties in that area. Although this study is not focused on professors' pedagogical practices, the students' academic difficulties in the field of exact sciences would be one of the research variables. A literature analysis reveals that a range of academic performance measures are investigated: grades (Aguilar, 2008; Artino et al., 2012; Costales \& Neira, 2011; Fernandez et al., 2012; Gomes \& Soares, 2013; Ihm et al., 2013; Nuñez Del Arco, 2005; Oyarzún Iturra et al., 2012; Victoroff \& Boyatzis, 2013); verbal report on academic performance (Hernández-Pozo et al., 2008; Turner et al., 2012); approval in a specific subject (Garzella, 2013; Martí Ballester, 2012) and attending the classes (Castaño-Perez \& Calderon-Vallejo, 2014). Studies are lacking that looked at the end product as a performance measure, which would be the graduation within the expected deadline. Research focusing on the academic outcome is justified by the possible negative social impacts of a graduation delay, such as the universities' financial expenses, besides possible disadvantages for the students and their family.

Also based on the literature review, a lack of studies is observed that consider a wide range of variables in the same sample, such as: social skills, mental health, academic performance, sociodemographic and academic characteristics. This study fits into these gaps, adopting instruments and a diagnostic measure of mental health problems to compare and verify the predictive value of social skills, mental health, 
sociodemographic variables, academic characteristics and college students' academic performance at the start of the undergraduate program for academic performance upon graduation, based on whether the student concluded the college program or not within the curricular deadline.

\section{Method}

\section{Participants}

The participants were 287 college students from a public university in the State of São Paulo, being 141 men and 146 women. The participants' mean age was 20 years, with a standard deviation of 3.16. The participants were taking undergraduate programs in exact sciences $(n=126)$, humanities $(n=111)$ and biological sciences $(n=50)$, totaling 35 classes.

The students who participated $(n=287)$ were part of a database of an earlier study conducted at a public university in the interior of the State of São Paulo, which initially involved 1392 undergraduates from different programs and years, aiming to study college students' mental health conditions and social skills. From this database, the students were selected who should already have concluded the program, considering the deadline specified in the curricula, and who complied with the following inclusion criteria: (a) when the social skills and mental health conditions were assessed, they were taking up to one semester before the middle of the program, defined as the start of graduation; (b) they had been assessed by means of the diagnostic tool Structured Clinical Interview for DSM-IV (SCID-1, $n=305$ ) and (c) in addition, students who took part in an exchange program $(n=18)$ as part of their undergraduate course were excluded, as this could be related to their non-conclusion of the course within the specific curricular deadline without any negative effect on their academic performance.

\section{Instruments}

Structured Clinical Interview for DSM-IV (SCID-I) clinical version, translated and adapted to Portuguese by DelBen et al. (2001). This unstructured clinical interview consists of five modules that permit the elaboration of psychiatric clinical diagnoses based on the DSM-IV. The interview was applied by telephone, a strategy described in the literature with good psychometric properties (Crippa et al., 2008). The SCID-IV has obtained good psychometric indicators with statistically significant reliability for different disorders (DelBen et al., 2001). This tool based on the DSM-IV was used, as the DSM-V is still recent and the corresponding version of the SCID is still being prepared.

Short version of the Social Phobia Inventory - Mini SPIN. This tool assesses indicators of social phobia, included in the study as a mental health measure to screen for indicators of anxiety or social phobia. It consists of three out of 17 items from the original Social Phobia Inventory (SPIN), in the checklist model, scored on a five-point Likert scale ranging from nothing to extremely. Proposed by Connor et al. (2000), it includes items six, nine and 15, which revealed to be better indicators of people with social anxiety disorder in the empirical study. In the original study, adopting six as the cut-off point, the inventory showed excellent sensitivity $(88.7 \%)$ and specificity indicators $(90 \%)$. In Brazil, the tool was translated and adapted by Osório (2008), with correlation coefficients of $.88(p<.01)$ for the full version of the SPIN, a Cronbach's alpha coefficient of .73 and good discriminative validity indicators when compared to the SCID, with an area under the curve corresponding to $.81(p<.01)$, a standard error of .02 with a $95 \%$ confidence interval. The cut-off point six presented sensitivity and specificity scores of .94 and .46 , respectively (Osório, 2008).

Beck Depression Inventory - BDI. Included in the study as a mental health measure, as a screener for depression indicators. The tool was translated, adapted and validated for the Brazilian population by Cunha (2001). It is selfadministered and consists of 21 items that assess the severity of depression symptoms, scored on a Likert scale from zero (absolutely not) to three (severely). Based on the total score, the inventory permits the ranking of depression levels into minimum, mild, moderate and severe. Originally created for use with psychiatric patients, this tool also demonstrated its suitability for use in the general population. In the study by Finger (2008), with the overall objective of validating the inventory for a Brazilian college population, data from 857 students showed the satisfactory psychometric properties of the BDI: Cronbach's alpha (.88) and good temporal stability $(r=.731)$.

Social Skills, Behaviors and Context Assessment Questionnaire for University Students (QHC-University Students). Was included in this study as a social skills measure because it distinguishes potentials and difficulties with regard to the social relationships. Proposed and verified by BolsoniSilva and Loureiro (2015), this inventory is divided in two parts. The first consists of 30 questions in which the participant should discuss how frequently (s)he interacts with different interlocutors concerning: (1) Communication (2) and Coping Speaking in public, which permits the identification of clinical and non-clinical anxiety and depression scores. In the second part, the student answers questions on the quality of social interactions with different interlocutors, in order to identify skillful and non-skillful responses and positive and negative consequences and feelings. These answers are organized in two factors, potentials and difficulties, permitting the classification of the behavioral standard as clinical and nonclinical with regard to anxiety and depression. Psychometric studies of the QHC - College Students have demonstrated satisfactory reliability (alpha .951) and discriminant validity in relation to the Mini Spin, BDI and SCID.

Protocol for Registering Academic Performance Data. This scheme for the systematic registering of official academic data was available on the university portal and was constructed to respond to the research objectives. For each participant, the following information was collected: (1) mean scores each participant obtained at the start of the program, defined as up to one semester before the middle of the course; (2) graduation within expected deadline 
(Yes/No) and (3) whether the student participated in an exchange program (Yes/No).

\section{Procedure}

Data collection. The data were collected at two distinct times in the participants' undergraduate program. The first is the start of the undergraduate program, when the students were taking up to one semester before the middle of the program. On this occasion, the data were collected in group, in the classroom, including the tools: Short version of the Social Phobia Inventory (Mini SPIN), Beck Depression Inventory (BDI) and Social Skills, Behaviors and Context Assessment Questionnaire for University Students (QHCUniversity Students). The SCID I was applied by telephone. The sociodemographic data, age, sex, type of housing and occupation, the participants' academic characteristics, year of undergraduate program, school year and class regimen (daytime, fulltime or nighttime) were collected by means of identification questions included in the QHC-University Students. At the same time, data were collected on the mean grades on all subjects the participants took in the semesters defined as the start of the program. Academic performance data were collected by consulting the official data from the Undergraduate Office of the university where the data were collected.

The second moment in the data collection is the deadline specified in the course curricula as the expected period for the participants to graduate. On this occasion, the official data from the Undergraduate Office were again consulted, focusing on the graduation or not within the specified deadline for each of the programs.

Data analysis. Concerning the Mini SPIN, the participants who scored six or higher were categorized as students with indicators of social phobia, while students who scored five or less were ranked as participants without indicators of social phobia. What the BDI is concerned, the participants with scores corresponding to the categories minimum and mild depression were considered as absent depression indicators, while participants scoring between moderate and severe depression were considered as present depression indicators. In the SCID-I, the category with mental disorder was used for participants diagnosed with one or more mental disorders, while the category without mental disorder applied to participants who did not comply with the criteria for any mental disorder.

As for the Academic Performance Protocol, after excluding those students who took an exchange program during the undergraduate course, the participants' grades for the start of the program were classified under average, below and above average in each course, based on the calculation of means and standard deviations. This measure was deemed necessary because the different courses presented typical means that were not mutually comparable. Besides the participants' grades at the start of the course, another academic performance measure was adopted: the graduation or not within the deadline for each course, leading to the ranking graduating vs. not graduating.
The sociodemographic data included and the respective categories used for the statistical analyses were as follows: sex (man and woman), employment (employed and not employed) and housing (student flat and family). The category marital status was not included because the sample was predominantly single. The following academic data and corresponding categories were included in the study: course area (Biological, Exact and Humanities), course regimen (daytime, fulltime and nighttime, but only the latter two were included because of the minimal number of subjects needed for the statistical analyses) and course year enrolled (first, second or third).

To compare the academic performance groups at the end of the program (graduating and not graduating), Student's t-test was applied for numerical variables and the Chi-Square test for categorical variables. The following criterion was adopted for the comparisons between graduating and non-graduating students: students who had not graduated within the deadline due to a student exchange program were excluded (assessed in this study as a criterion of good academic performance that would not justify the consideration of these participants as not graduating). In the results, the categories are presented with statistical differences at $5 \%$.

To verify the predictive value of the variables assessed at the start of the program, social skills, mental health and mean academic performance, and also of the sociodemographic and academic characteristics at the end of the program, binary logistic regression was used. In the initial model, only the variables that distinguished the groups were included by means of Student's t-test or the Chi-Square test, adopting $p<$ .1 , and thus avoiding multicollinearity.

\section{Ethical Considerations}

The background study that originated the initial database received approval from the Research Ethics Committee (CEP) at Universidade Estadual Paulista "Júlio de Mesquita Filho", under protocol 1315/46/01/07, involving data collection directly from the participants, who signed the Informed Consent Term (ICT) and were guaranteed secrecy, the possibility to quit participating without negative consequences, advice and psychological assistance. For the phase exclusive to this study, concerning the collection of documentary data on the participants' academic performance, the CEP waived the signing of the ICT under protocol $534.933(05 / 02 / 2014)$.

\section{Results}

In this part, the results are presented for the comparisons graduating $\mathrm{x}$ not graduating (Student's $\mathrm{t}$ and Chi-Square test), specifying the numerical and categorical variables with statistically significant differences: social skills (anxiety), academic performance at the start of the program, sociodemographic variables and academic variables.

Table 1 presents the comparisons for the general social skills and social skills of college students, distinguished by the presence of anxiety indicators between groups of graduating and non-graduating students. 
Table 1

Comparisons of General Social Skills and Social Skills of College Students, Distinguished by the Presence of Anxiety Indicators Between Groups of Graduating and Non-Graduating Students

\begin{tabular}{|c|c|c|c|c|c|}
\hline \multirow[b]{2}{*}{ Social Skills } & & \multicolumn{2}{|c|}{ Academic Performance } & \multirow[b]{2}{*}{$t^{*}$} & \multirow[b]{2}{*}{$p$} \\
\hline & & $\begin{array}{l}\text { Graduating } \\
M(S D)\end{array}$ & $\begin{array}{c}\text { Non-Graduating } \\
M(S D)\end{array}$ & & \\
\hline QHC Communication and affect (F1) & & $21.24(5.40)$ & $19.99(5.52)$ & 1.908 & .057 \\
\hline \multirow[t]{2}{*}{ QHC- Speaking in public (F3) } & & $4.43(1.86)$ & $3.99(1.73)$ & 2.045 & .042 \\
\hline & & \multicolumn{2}{|c|}{ Anxiety } & $\chi^{2}$ & $p$ \\
\hline \multirow{2}{*}{ QHC- Communication and affect (F1) } & Present & $70(53.03)$ & $62(46.97)$ & \multirow{2}{*}{3.895} & \multirow{2}{*}{.048} \\
\hline & Absent & $100(64.52)$ & $55(35.48)$ & & \\
\hline
\end{tabular}

* Student's t-test. $p \leq .05$.

In Table 1 , it is shown that, among the general social skills in the QHC-University Students, the factors that indicated a statistically significant difference between the groups of graduating and non-graduating students were F1Communication and affect, F3-Speaking in public, with higher mean social skills scores among the graduating participants. As for the comparisons between college students according to the presence of anxiety indicators, statistically significant differences were found between the graduating and non-graduating groups according to F1-Communication and affect, showing that more participants without anxiety indicators concluded the undergraduate program within the established deadline.

The comparisons between the mean academic performance at the start of the course, sociodemographic and academic characteristics of graduating and nongraduating groups within the deadlines are displayed in Table 2.

Table 2

Comparisons of Academic Performance Indicators at the Start of the Course, Sociodemographic and School Variables in the Groups of Graduating and Non-Graduating College Students

\begin{tabular}{|c|c|c|c|c|}
\hline & \multicolumn{2}{|c|}{ Academic Performance } & \multicolumn{2}{|c|}{ Statistics } \\
\hline & $\begin{array}{c}\text { Graduating } \\
F(\%)\end{array}$ & $\begin{array}{c}\text { Non-Graduating } \\
F(\%)\end{array}$ & $\chi^{2 *}$ & $p$ \\
\hline \multicolumn{5}{|c|}{ Academic Performance at the Start of the Course } \\
\hline Below average & $14(29.79)$ & $33(70.21)$ & \multirow[t]{3}{*}{20.182} & \multirow[t]{3}{*}{.001} \\
\hline Average and/or above average & $156(65.00)$ & $84(35.00)$ & & \\
\hline & Sociodemographic $\mathrm{v}$ & & & \\
\hline \multicolumn{5}{|l|}{ Sex } \\
\hline Man & $64(45.39)$ & $77(54.61)$ & \multirow{3}{*}{21.997} & \multirow{3}{*}{.001} \\
\hline Woman & $106(72.60)$ & $40(27.40)$ & & \\
\hline & School variabl & & & \\
\hline \multicolumn{5}{|l|}{ Years } \\
\hline 1st Year & $69(44.80)$ & $85(55.20)$ & \multirow{3}{*}{28.660} & \multirow{3}{*}{.001} \\
\hline 2nd Year & $83(76.15)$ & $26(23.85)$ & & \\
\hline 3rd Year & $18(75.00)$ & $6(25.00)$ & & \\
\hline \multicolumn{5}{|l|}{ Areas } \\
\hline Biological & $33(66.00)$ & $17(34.00)$ & \multirow{3}{*}{16.593} & \multirow{3}{*}{0.001} \\
\hline Exact & $58(46.03)$ & $68(53.97)$ & & \\
\hline Humanities & $79(71.82)$ & $32(28.18)$ & & \\
\hline
\end{tabular}

*Chi-square test, $p \leq .05$. 
As observed in Table 2, graduating groups included a larger proportion of students with average and/or aboveaverage performance at the start of the course, female, thirdyear students enrolled in humanities.
In Table 3, the Binary Logistic Regression results are described, considering the categories related to social skills, mental health, sociodemographic and academic variables for academic performance at the end of the course (graduating and not graduating).

Table 3

Logistic Regression Considering the Categories Related to Social Skills, Mental Health, Sociodemographic and School Variables for Academic Performance at the End of the Course (Graduating and Non-Graduating)

\begin{tabular}{lccccc}
\hline Variables & OR & $95 \%$ CI & $p^{*}$ & Tolerance & VIF \\
\hline Sex & 0.647 & {$[1.040,3.511]$} & .037 & .810 & 1.234 \\
Course year & 1.933 & {$[2.275,20.981]$} & .001 & .915 & .093 \\
Course area & 0.180 & {$[0.521,2.751]$} & .110 & .001 & .373 \\
Academic performance start & 2.791 & {$[5.191,51.156]$} & .186 & 2.678 \\
\hline
\end{tabular}

*Statistics: Binary Logistic Regression, $p \leq .01$.

Table 3 displays the predictive variables of academic performance at the end of the program. Among all variables analyzed (sex; age; occupation; type of housing (family or student flat); course year at the time of the assessment; course year; course regimen; mental health problems based on screeners for depression, anxiety and diagnostic assessment of SCID and social skills), eight presented statistically significant differences, being: Sex, Course year, Areas and Initial Academic Performance; factors of QHC-University Students, F1 - Communication and Affect, F3 - Speaking in Public, F1 - Communication and Affect for Anxiety, Potentials for Anxiety. The following variables continued in the final model: sex, course area, course year and initial academic performance; the female sex, the area of humanities and average or above-average initial academic performance were the predictive variables of graduation within the established deadline.

\section{Discussion}

The data analysis evidenced that the variables female sex, area of humanities, taking the more advanced years of the undergraduate program at the moment of the first assessment and average or above-average initial academic performance were predictors of graduation within the established deadline.

Social skills did not continue in the final logistic regression model, but distinguished the groups in the univariate analyses, indicating higher mean scores among the graduating students for the factors F1 - Communication and Affect and F3 - Speaking in public. Based on the differences found, it is speculated that the college students who reported greater skills at expressing affect and communicating probably constructed a useful social support network for the learning relationship, and that public speaking skills may have facilitated some academic tasks directly related with academic performance, such as presenting seminars. One could also consider that the natural training of the social skills involved in academic tasks during the course may have contributed to the students' academic performance. The positive relationship between social skills and academic performance is in line with the findings of other studies in which a similar treatment was adopted (Aguilar, 2008; Artino et al., 2012; Fernandez et al., 2012; Oyarzún Iturra et al., 2012; Victoroff \& Boyatzis, 2013), except for the study by Nuñez Del Arco (2005), which found no significant relations between academic performance and social skills. A peculiar characteristic of the latter study is the exclusive inclusion of Psychology students, suggesting possible particularities for that population.

In view of the data obtained through the logistic regression analysis, the results obtained in this study diverged from other studies adopting the same method, as Gomes and Soares (2013) identified that the positive or negative relationship among the research variables varied according to the social skills factors; Ihm et al. (2013) found that interpersonal communication skills were negatively related with academic performance. In the attempt to understand these divergences, some differences in terms of study design should be highlighted, as Gomes and Soares (2013) and Ihm et al. (2013) did not consider the graduation in their studies, but focused on other moments in the course. Another noteworthy point is that, perhaps, the academic performance assessment at this college was not sensitive to the social skills, as the study behavior can often guarantee good grades independently of the student's social repertoire, as appointed in Ihm et al. (2013).

Concerning the sociodemographic variables, the female sex was maintained in the logistic regression analysis, in line with the results of the study by Martí Ballester (2012) involving students from the exact sciences. In a context of unequal rights between the genders, it was observed that women could engage in behaviors that facilitate good academic performance as a strategy to cope with this scenario. The current study permitted a broader analysis by including a larger number of courses, indicating that women's better academic performance was not exclusive to the area of exact sciences. With regard to the academic variables, 
the variable course area continued in the final regression model. Students from humanities more frequently concluded the program within the deadline, followed by students in biological and exact sciences. The performance difficulty identified for college students in exact sciences, verified in this study, is in accordance with the study by Garzella (2013), which found a large number of students who did not pass the subject Calculus I, a finding the researcher related with the teachers' educational skills and with the curricular structure of undergraduate programs in this area. This study did not focus on the teaching practices, but the results found here once again suggest academic performance difficulties for students in exact sciences, which may derive, for example, from the teachers' didactical difficulties and/or the nature of the specific course activities. In the current study, this result could be verified in comparison with the other knowledge areas.

The academic variable course year was maintained in the logistic regression model, showing that the students in more advanced course years at the time of the social skills and mental health assessment graduated within the deadline more frequently, indicating that the students with good academic performance at the start of the course maintained this pattern until they graduated. This result is in line with the findings for the variable academic performance at the start of the course, which was maintained in the logistic regression model, showing that good performance at the start of the course contributed to the good academic performance at the end of the course. According to a systematic literature review undertaken for the sake of this study, the relation between initial and final academic performance at the undergraduate level has not been investigated earlier in the literature in the area, representing a contribution of this study and advancing in this field of knowledge.

The mental health variable did not serve as a predictor of academic performance but, in the univariate analyses, it was verified that the college students who did not graduate presented higher anxiety scores. This relation between mental health problems and academic performance was also verified in other comparative studies on different mental health problems (Castaño-Perez \& Calderon-Vallejo, 2014; Gonçalves et. al., 2012; Hernández-Pozo et al., 2008). The result found in this study in terms of prediction differed from the result observed in the literature, which predominantly indicates that good mental health conditions predict good academic performance (Bajwa et al., 2013; Costa et al., 2012; Costales \& Neira, 2011; Turner et al., 2012). As verified for social skills, the studies cited were not longitudinal like this research, which can explain the different results. The current study also suggests that both mental health and social skills may have interfered in the students' initial academic performance, which in turn predicted the graduation. This suggests that future studies should investigate the relations between social skills and mental health at the start of the course.

It was verified that the variables female sex, in the area of humanities and good initial academic performance predicted graduation within the deadline. The social skills and mental health distinguished between the graduating and nongraduating groups but did not predict the graduation within the deadline.

Although these data do not confirm the main hypothesis that good social skills and mental health conditions predict good academic performance at the end of the course, this study did offer several contributions. With a longitudinal design and a sample of college students from humanities, exact and biological sciences, a large number of variables were investigated. The exclusive participation of college students from a single public university in the State of São Paulo, the use of verbal reports to assess social skills and mental health and the lack of process-based academic performance measures are highlighted as limitations.

This study advanced on the knowledge about the variables that favor graduation, emphasizing the impact of academic performance at the start of the course, the humanities area and the course year as decisive conditions for this outcome. As a further deployment of these findings, the relevance of proposing preventive measures is underlined, in order to favor the students' academic performance in the initial phases of the course. The promotion of protective conditions for male students in the exact and biological areas should be particularly promoted. In addition, future studies are suggested, focusing on teachers' didactical skills, the study behaviors of college students, students from public and private colleges, from different states and the relevance of social skills in college curricula.

\section{References}

Aguilar, S. M. (2008). Asertividad escolar em alumnos de la licenciatura en psicología [School assertiveness in psychology students] (Trabalho de conclusão de curso não publicado). Universidad Pedagógica Nacional, México, MX.

Artino, A. R., Jr., Dong, T., DeZee, K. J., Gilliland, W. R., Waechter, D. M., Cruess D., \& Durning, S. J. (2012). Achievement goal structures and self-regulated learning: Relationships and changes in medical school. Academic Medicine: Journal of the Association of American Medical Colleges, 87(10), 1375-1381. doi:10.1097/ ACM.0b013e3182676b55

Bajwa, H. Z., Al Turki, A. S. A., Dawas, A. M. K., Behbehani, M. Q., Al-Mutairi, A. M. A., Al-Mahmoud, S., \& Thalib, L. (2013). Prevalence and factors associated with the use of illicit substances among male university students in Kuwait. Medical Principles and Practice, 22(5), 458-463. doi:10.1159/000350609

Bolsoni-Silva, A. T., \& Loureiro, S. R. (2015). Questionário de avaliação de comportamentos e contextos para universitários: Manual técnico. QHC - Universitários [Behaviors and Context Assessment Questionnaire for University Students: Technical Manual. QHC- University Students]. São Paulo, SP: Cetepp. 
Borges, P. (2012). MEC e universidades estudam planos para combater evasão [MEC and universities study plans to combat evasion]. Recuperado de http://ultimosegundo. ig.com.br/educacao/mec-e-universidades-estudamplanos-para-combater-evasao/n1597622390779.html

Castaño-Perez, G. A., \& Calderon-Vallejo, G. A. (2014). Problems associated with alcohol consumption by university students. Revista Latino-Americana de Enfermagem, 22(5), 739-746. doi:10.1590/01041169.3579 .2475

Connor, K. M., Davidson, J. R. T., Churchill, L. E., Sherwood, A., Weisler, R. H., \& Foa, E. (2000). Psychometric properties of the Social Phobia Inventory (SPIN): A new self-rating scale. British Journal of Psychiatry, 176(4), 379-386. doi:10.1192/bjp.176.4.379

Costa, E. F. O., Santana, Y. S., Santos, A. T. R. A., Martins, L. A. N., Melo, E. V., \& Andrade, T. M. (2012). Sintomas depressivos entre internos de medicina em uma universidade pública brasileira [Depressive symptoms among medical intern students in a Brazilian public university]. Revista da Associação Médica Brasileira, 58(1), 53-59. doi:10.1590/S0104-42302012000100015

Costales, F., \& Neira, F. (2011). Variables que influencias el rendimiento académico en los estudiantes de la UISEK Ecuador [Variables that influence the academic performance of UISEK Ecuador students]. Anuario de la Universidad International SEK, 12, 15-20. Retrieved from https://www.yumpu.com/es/document/view/37772811/ variables-que-influencias-el-rendimiento-acadacmico-enlos-

Crippa, J. A. S., Osório, F. L., Del-Ben, C. M., Santos Filho, A., Freitas, M. C. S., \& Loureiro, S. R. (2008). Comparability between telephone and face-to-face structured clinical interview for DSM-IV in assessing social anxiety disorder. Perspectives in Psychiatric Care, 44(4), 241-247. doi:10.1111/j.1744-6163.2008.00183.x

Cunha, J. A. (2001). Manual da versão em português das Escalas Beck [Portuguese version of the Beck Scales]. São Paulo, SP: Casa do Psicólogo.

Del-Ben, C. M., Vilela, J. A. A., Crippa, J. A. S., Hallak, J. E. C., Labate, C. M., \& Zuardi, A. W. (2001). Confiabilidade da "Entrevista Clínica Estruturada para o DSM-IV Versão clínica" traduzida para o português [Reliability of the Structured Clinical Interview for DSM-IV - Clinical version translated into Portuguese]. Revista Brasileira de Psiquiatria, 23(3), 156-159. doi:10.1590/S151644462001000300008

Fernandez, R., Salamonson, Y., \& Griffiths, R. (2012). Emotional intelligence as a predictor of academic performance in first-year accelerated graduate entry nursing students. Journal of Clinical Nursing, 21(23-24), 3485-3492. doi:10.1111/j.1365-2702.2012.04199.x
Finger, I. R. (2008). Validade de construto do Inventário de depressão de Beck- II (BDI-II) em uma população universitária [Validity of the construction of the Beck-II depression inventory (BDI-II) in a university population] (Master's thesis). Retrieved from http://tede.pucrs.br/ tde arquivos/20/TDE-2009-03-05T054023Z-1700/ Publico/409553.pdf

Garzella, F. A. C. (2013). A disciplina de Cálculo I: Análise das relações entre as práticas pedagógicas do professor e seus impactos nos alunos [The subject of Calculus I: analysis of the relations between teacher's pedagogical practice and its impact in students] (Doctoral dissertation). Retrieved from https://www.fe.unicamp.br/alle/teses dissert_tcc/arquivos/tesefabianacolombo.pdf

Gomes, G., \& Soares, A. B. (2013). Inteligência, habilidades sociais e expectativas acadêmicas no desempenho de estudantes universitários [Intelligence, social skills and academic expectations in university students' performance]. Psicologia: Reflexão e Crítica, 26(4), 780789. doi:10.1590/S0102-79722013000400019

Gonçalves, V., Zidan, A., Issa, M., \& Barah, F. (2012). A longitudinal investigation of depressive symptoms in undergraduate students of pharmacy in Syria. The Journal of Nervous and Mental Disease, 200(5), 395-400. doi:10.1097/NMD.0b013e3182532062

Hernández-Pozo, M. R., Coronado Álvarez, O., Araújo Contreras, V., \& Cerezo Reséndiz, S. (2008). Desempeño académico de universitarios em relación con ansiedad escolar y auto-evaluación [Academic performance, selfevaluation, and school anxiety among college students]. Acta Colombiana de Psicologia, 11(1), 13-23. Retrieved from http://www.researchgate.net/publication/28242861_ Desempeo_acadmico_de_universitarios_en_relacin_con_ ansiedad_escolar_y_auto-evaluacin

Ihm, J. J., Lee, G., Kim, K. K., Jang, K. T., \& Jin, B. H. (2013). Who succeeds at dental school? Factors predicting students' academic performance in a dental school in republic of Korea. Journal of Dental Education, 77(12), 1616-1623. Retrieved from http://www.jdentaled.org/ content/77/12/1616.full.pdf + html

Martí Ballester, C. P. (2012). Análisis de los factores que influyen en el desempeño académico de los alumnos de contabilidad financiera a través de modelos de elección binaria [Analysis of the factors that influence the academic performance of financial accounting students using binary choice models]. Revista Brasileira de Gestão de Negócios, 14(45), 379-399. Retrieved from http://www.redalyc.org/ articulo.oa?id=94725812002

Nuñez Del Arco, C. R. G. (2005). Habilidades sociales, clima social familiar y rendimiento académico en estudiantes universitarios [Social skills family social climate and academic yield in university students]. Liberabit, 11(11), 63-74. Retrieved from http://pepsic.bvsalud.org/scielo. php?script=sci_arttext\&pid=S1729-48272005000100008 
Osório, F. L. (2008). Transtorno de ansiedade social: Validação de instrumentos de avaliação [Social anxiety disorder: Validation of assessment instruments] (Doctoral dissertation). Retrieved from http://www.teses.usp.br/ teses/disponiveis/17/17148/tde-02082010-095542/pt-br. php

Oyarzún Iturra, G., Estrada Goic, C., Pino Astete, E., \& Oyarzún Jara, M. (2012). Habilidades sociales y rendimiento académico: Una mirada desde el género [Social skills and academic achievement: A gender point of view]. Acta Colombiana de Psicologia, 15(2), 21-28. Retrieved from http://www.scielo.org.co/pdf/acp/v15n2/ v15n2a03.pdf

Turner, D. P., Thompson, M. E., Huber, L. R. B., \& Arif, A. A. (2012). Depressive symptoms and academic performance of North Carolina college students. North Carolina Medical Journal, 73(3), 169-175.

Victoroff, K. Z., \& Boyatzis, R. E. (2013). What is the relationship between emotional intelligence and dental student clinical performance? Journal of Dental Education, 77(4), 416-426. Retrieved from http://www. jdentaled.org/content/77/4/416.full.pdf + html

Alessandra Salina Brandão is a Clinical psychologist at the Bauru Behavior Analysis Institute.

Alessandra Turini Bolsoni-Silva is an Adjunct Professor of the Universidade Estadual Paulista "Júlio de Mesquita Filho".

Sonia Regina Loureiro is a Professor of the Universidade de São Paulo.

Received: Sep. 21, 2015

1st Revision: Jan. 28, 2016

Approved: Mar. 1, 2016

How to cite this article:

Salina-Brandão, A., Bolsoni-Silva, A. T., \& Loureiro, S. R. (2017). The predictors of graduation: Social skills, mental health, academic characteristics. Paidéia (Ribeirão Preto), 27(66), 117-125. doi: 10.1590/1982-43272766201714 